\title{
Makrozoobentos sebagai bioindikator kualitas perairan di Desa Pengujan Kabupaten Bintan
}

\section{Makrozoobentos as a bioindicator of water quality in Pengujan Village, Bintan Regency}

\author{
Rizkia Nurul Fadilla ${ }^{1}$, Winny Retna Melani ${ }^{1, *}$, Tri Apriadi ${ }^{1}$ \\ ${ }^{1}$ Program Studi Manajemen Sumberdaya Perairan, Fakultas Ilmu Kelautan dan Perikanan, Universitas Maritim Raja \\ Ali Haji, Jl. Politeknik Senggarang Tanjungpinang 29111, Indonesia
}

Received 5 Mei $2021 \quad$ Received in revised 26 Juli $2021 \quad$ Accepted 30 Agustus 2021

\section{ABSTRAK}

Makrozoobentos adalah salah satu indikator biologi yang dapat dijadikan acuan dalam penilaian kualitas lingkungan di berbagai ekosistem perairan. Penelitian ini bertujuan untuk mengetahui kualitas perairan di Desa Pengujan berdasarkan indikator biologis makrozoobentos. Penelitian ini dilakukan pada bulan Januari-Februari 2021 yang berlokasi di Desa Pengujan Kabupaten Bintan. Pengambilan sampel dilakukan dengan metode purposive sampling terdiri dari 5 stasiun pengamatan. Pengambilan sampel makrozoobentos menggunakan transek kuadran berukuran $1 \times 1$ $\mathrm{m}^{2}$. Parameter yang diamati meliputi kualitas perairan (parameter fisika dan kimia), serta jenis dan kepadatan makrozoobentos. Parameter fisika dan kimia perairan dibandingkan nilai Baku Mutu berdasarkan PP RI No. 22 Tahun 2021, sedangkan analisis AMBI (A Marine Biotic Index) digunakan untuk mengetahui kualitas perairan berdasarkan keberadaan makrozoobenthos. Hasil pengukuran parameter perairan masih berada pada ambang batas baku mutu PP RI No 22 Tahun 2021 kecuali untuk parameter nitrat dan fosfat yang tidak memenuhi baku mutu di setiap stasiunnya. Kepadatan makrozoobentos tertinggi yaitu pada stasiun 3 yang berada pada kawasan dermaga, sedangkan kepadatan terendah yaitu pada stasiun 5 yang berada pada kawasan penangkapan siput gonggong. Kualitas perairan berdasarkan makrozoobentos sebagai bioindikator perairan dengan indeks AMBI semua stasiun termasuk dalam kategori sedikit tercemar.

Kata kunci: AMBI, Bintan, bioindikator, makrozoobentos, Pengujan

\begin{abstract}
Macrozoobenthos is one of the biological indicators that can be used in environmental quality assessment in various aquatic ecosystems. The objective of this study was to determine the water quality in Pengujan Village based on macrozoobenthos biological indicators. This research was conducted in January-February 2021 located in Pengujan Village, Bintan Regency. Sampling was done by purposive sampling method in 5 observation stations. Macrozoobenthos was collected used a quadrant transect $\left(1 \times 1 \mathrm{~m}^{2}\right)$. Parameters observed included water quality (physical and chemical parameters), as well as the type and density of macrozoobenthos. Physical and chemical parameters of the waters were compared to the value of the Quality Standards based on PP RI No. 22 of 2021, while AMBI (A Marine Biotic Index) analysis is used to determine water quality based on the presence of macrozoobenthos. The results of the measurement of water parameters are meet of the quality standard of PP RI No. 22 of 2021, except for the nitrate and phosphate parameters that do not meet the quality standards at each station. The highest density of macrozoobenthos is at station 3 which is in the dock area, while the lowest density is at station 5 which is in the barking snail catching area. Water quality based on macrozoobenthos as a water bioindicator with AMBI index all stations are included in the slightly polluted category.
\end{abstract}

Keywords: AMBI, Bintan, bioindicator, macrozoobenthos, Pengujan 


\section{Pendahuluan}

Desa Pengujan merupakan salah satu desa di Kecamatan Teluk Bintan yang mempunyai luas wilayah mencapai \pm 4.973 Ha dengan jumlah penduduk sebanyak 1.436 jiwa (Pengujan Simdes Bintan 2021). Desa Pengujan merupakan kawasan pesisir yang memiliki objek wisata kuliner. Konsumsi dan penghasilan sebagian masyarakat Desa Pengujan dari hasil laut, seperti ikan, kerang, serta biota laut lainnya. Seiring dengan pembangunan wilayah dan pengembangan daerah, saat ini aktivitas masyarakat di Desa Pengujan cukup padat seperti adanya keramba jarring apung (KJA), balai benih ikan milik Pemerintah Daerah Kabupaten Bintan, dermaga, area penangkapan ikan, kerang, dan siput gonggong (Strombus sp.), serta kawasan pemukiman masyarakat. Hal tersebut memungkinkan adanya buangan limbah domestik secara langsung maupun tidak langsung ke dalam perairan. Kondisi Desa Pengujan yang tidak terlepas dari berbagai aktivitas masyarakat ini dapat memengaruhi kondisi laut di perairan Desa Pengujan.

Aktivitas masyarakat di sekitar pesisir diduga berpengaruh terhadap kualitas perairan. Masuknya pencemar organik dan anorganik ke badan air perairan pesisir pantai diduga dapat menyebabkan penurunan kualitas perairan diikuti dengan perubahan fisika, kimia, dan biologi. Potensi perairan pesisir pantai dan laut sebagai sumber pangan bagi masyarakat akan terganggu. Berbagai aktivitas manusia yang ada di wilayah pesisir di Desa Pengujan dikhawatirkan berpotensi menimbulkan pencemaran terhadap kondisi kualitas perairan yang berdampak pada kerusakan habitat serta penurunan keanekaragaman biota pesisir, salah satunya adalah makrozoobentos.

Makrozoobentos adalah salah satu indikator biologi yang dapat dijadikan acuan dalam penilaian kualitas lingkungan di berbagai ekosistem perairan (Prihatin et al. 2021; Safitri et al. 2021; Rosdatina et al. 2019; Apriadi et al. 2020). Penggunaan makrozoobentos sebagai bioindikator didasari atas perbedaan kemampuan makrozoobenthos dalam merespon perubahan beberapa parameter lingkungan. Beberapa kajian mengenai makrozobentos yang telah dilakukan di Perairan Desa Pengujan antara lain mengenai hubungan kerapatan lamun dengan kelimpahan makrozoobenthos (Junaidi 2017); keanekaragaman gastopoda (Putra 2015); serta tingkat pemanfaatan siput gonggong / Strombus sp. (Armanda 2018). Kajian struktur komunitas makrozoobenthos serta kaitannya dengan pendugaan kualitas perairan belum dilaporkan. Penelitian ini bertujuan untuk mengetahui kualitas perairan di Desa Pengujan berdasarkan indikator biologis makrozoobentos.

\section{Metodologi}

\subsection{Waktu dan Lokasi Penelitian}

Penelitian ini dilaksanakan pada JanuariFebruari 2021, berlokasi di Perairan Desa Pengujan, Kabupaten Bintan, Provinsi Kepulauan Riau. Peta lokasi penelitian disajikan dalam Gambar 1. Pengambilan sampel dan pengukuran parameter lingkungan perairan dilakukan di lima stasiun sebagai berikut:

- Stasiun 1 merupakan kawasan Karamba Jaring Apung (KJA)

- Stasiun 2 merupakan kawasan tanpa aktivitas masyarakat dan terdapat ekosistem lamun.

- Stasiun 3 merupakan kawasan dermaga.

- Stasiun 4 merupakan kawasan permukiman penduduk dan terdapat ekosistem mangrove.

- Stasiun 5 merupakan kawasan penangkapan siput gonggong dan terdapat ekosistem lamun.

\subsection{Alat dan Bahan}

Alat yang digunakan yaitu multitester YK2005WA, GPS, hand refractometer, TDS meter, sekop, transek $1 \times 1 \mathrm{~m}$, kamera, cool box, oven, alat tulis, saringan bertingkat, dan botol sampel. Bahan yang digunakan yaitu aquades, tisu, kantong sampel, alkohol $70 \%$, kertas label, pewarna rose bengal, serta buku identifikasi (FAO 1998).

\subsection{Metode Penelitian}

Penelitian dimulai dengan tahapan pengukuran parameter fisika-kimia perairan di lapangan. Parameter insitu yang diukur di lapangan antara lain oksigen terlarut (dissolved oxygen / DO), $\mathrm{pH}$, dan suhu menggunakan multitester, kecerahan menggunakan Secchi disk, Total Dissolved Solid (TDS) menggunakan TDS meter, serta salinitas 
menggunakan hand refractometer. Pengukuran parameter insitu di lapangan dilakukan sebanyak 3 kali ulangan di setiap titik. Setelah itu dilakukan pengambilan sampel air untuk analisis Total Suspended Solid (TSS), dan Biological Oxygen Demand (BOD). Sampel air disimpan ke dalam coolbox untuk selanjutnya dilakukan analisis di laboratorium berdasarkan acuan APHA (2017). Sampel sedimen diambil menggunakan sekop. Sampel lalu dimasukkan ke dalam plastik untuk keperluan analisis Total Organic Matter (TOM) di sedimen dan penentuan tipe/ jenis substrat. Tekstur substrat dikelompokkan berdasarkan grafik segitiga Shepard (Arhat et al. 2014).

Pengamatan sampel makrozoobentos dilakukan pada saat kondisi air surut. Pengambilan sampel makrozoobentos epifauna dan infauna menggunakan transek kuadran yang berukuran $1 \times 1 \mathrm{~m}$ sebanyak tiga kali pengulangan di setiap stasiun. Sampel sedimen yang berada di dalam transek 1x1 m dengan kedalaman 5-10 $\mathrm{cm}$ diambil menggunakan sekop lalu disaring. Biota yang berukuran besar dimasukkan ke dalam kantong plastik dan diberi pengawet alkohol $70 \%$ dan rose bengal. Sedangkan sedimen yang tertahan di saringan dimasukkan ke kantong plastik lainnya dan diberi pengawet alkohol $70 \%$ dan rose bengal untuk dilakukan penyortiran di laboratorium. Penyortiran dan identifikasi makrozoobentos dilakukan di Laboratorium Biologi Kelautan FIKP menggunakan mikroskop stereo. Identifikasi berdasarkan acuan FAO (1998). Bentos yang sudah diidentifikasi lalu dihitung jumlah individu untuk dihitung kepadatannya

\subsection{Analisis Data}

\subsubsection{Kelimpahan Makrozoobentos}

Makrozoobentos yang diperoleh kemudian dihitung kelimpahan jenisnya dalam jumlah individu/ha dengan menggunakan rumus sebagai berikut Odum (1993).

$$
\mathrm{D}=\frac{\mathrm{Z}}{\mathrm{A}}: 0,0001
$$

Keterangan:

D : Kelimpahan jenis (individu $/ \mathrm{m}^{2}$ )

$\mathrm{z} \quad$ : Jumlah individu setiap jenis

A : Luas area pengamatan $\left(\mathrm{m}^{2}\right)$

0,0001 : konversi $\mathrm{m}^{2} \mathrm{ke}$ ha

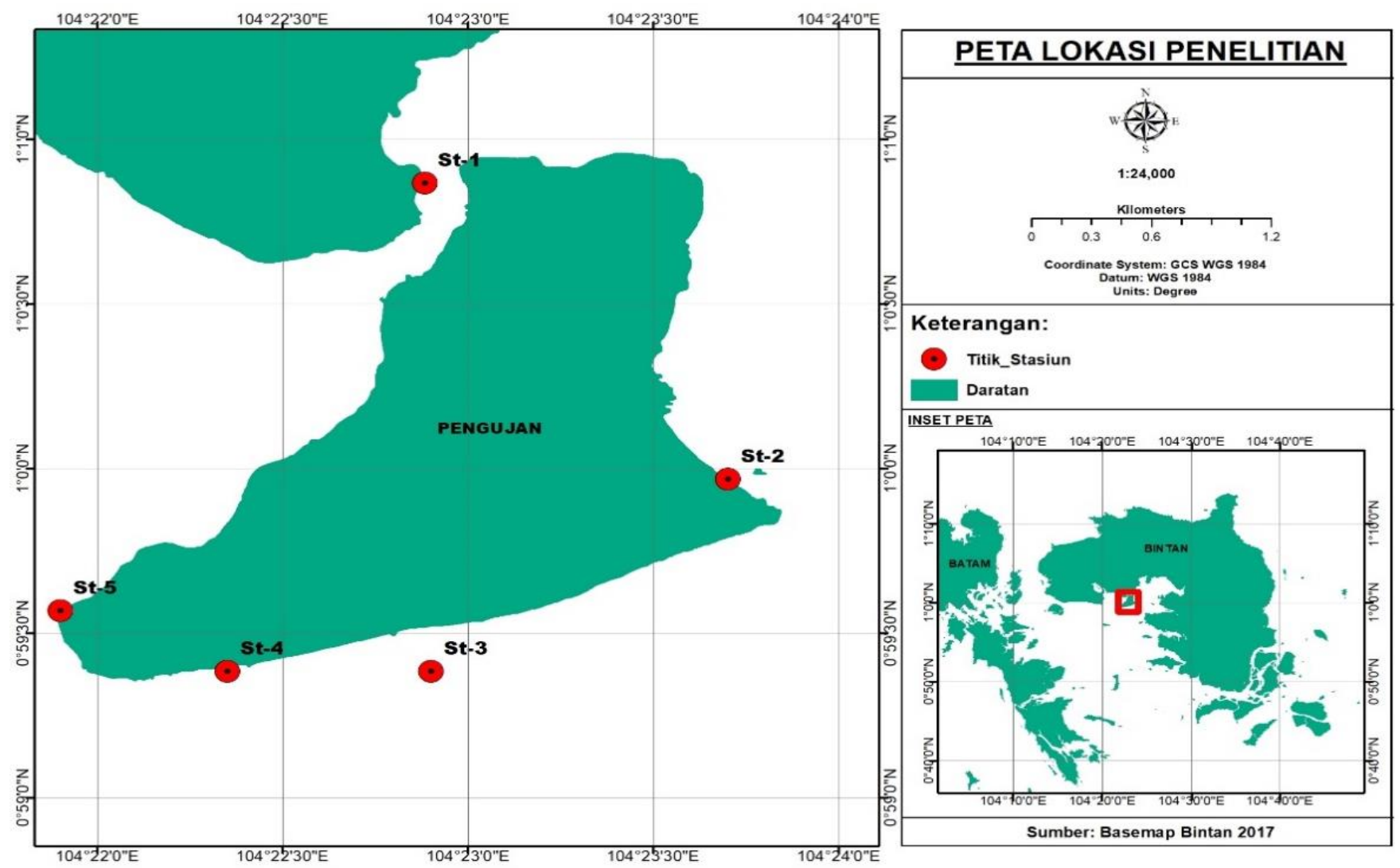

Gambar 1. Peta lokasi penelitian di Perairan Desa Pengujan. 
Tabel 1. Klasifikasi polusi berdasarkan nilai AMBI.

\begin{tabular}{lcccl}
\hline Klasifikasi polusi & $\begin{array}{c}\text { Koefisien } \\
\text { biotik }\end{array}$ & Indeks biotik & $\begin{array}{c}\text { Dominansi } \\
\text { kelompok ekologis }\end{array}$ & Komunitas bentik \\
\hline Tidak tercemar & $0,0<\mathrm{BC} \leq 0,2$ & 0 & $\mathrm{I}$ & Normal \\
Tidak tercemar & $0,2<\mathrm{BC} \leq 1,2$ & 1 & & Miskin \\
Sedikit tercemar & $1,2<\mathrm{BC} \leq 3,3$ & 2 & III & Tidak seimbang \\
Tercemar sedang & $3,3<\mathrm{BC} \leq 4,3$ & 3 & & Transisi ke tercemar \\
Tercemar sedang & $4,5<\mathrm{BC} \leq 5,0$ & 4 & IV-V & Tercemar \\
Tercemar berat & $5,0<\mathrm{BC} \leq 5,5$ & 5 & & Transisi ke tercemar berat \\
Tercemar berat & $5,5<\mathrm{BC} \leq 6,0$ & 6 & $\mathrm{~V}$ & Tercemar berat \\
Sangat tercemar & Azoic & 7 & Azoic & Azoic \\
\hline
\end{tabular}

\subsubsection{Indeks Keanekaragaman $\left(H^{I}\right)$}

Keanekaragaman jenis makrozoobentos dihitung dengan indeks keanekaragaman Shannon-Wiennersebagai berikut (Krebs 2014).

$$
\mathrm{H}^{\prime}=-\sum_{\mathrm{Pi}=\frac{\mathrm{ni}}{\mathrm{N}}} \mathrm{Pi} \ln \mathrm{Pi}
$$

Keterangan:

$\mathrm{H}^{\prime}$ : Indeks keanekaragaman

ni : jumlah individu masing masing jenis

$\mathrm{S}$ : jumlah spesies yang ditemukan

Kategori indeks keanekaragaman ShannonWienner:

$0<\mathrm{H}^{\prime}<2,302$ : keanekaragaman rendah $2,302<\mathrm{H}^{\prime}<6,907$ : keanekaragaman sedang $\mathrm{H}^{\prime}>6,907 \quad$ : keanekaragaman tinggi

\subsubsection{Indeks Keseragaman (E)}

Tingkat keseragaman jenis makrozoobentos menggambarkan keseragaman jumlah populasi antar jenis suatu makhluk hidup pada suatu komunitas (Efriningsih et al. 2016). Indeks keseragaman di rumuskan sebagai berikut (Krebs 2014).

$$
\mathrm{E}=\frac{\mathrm{H}^{\prime}}{\mathrm{H}_{\max }}=\frac{\mathrm{H}^{\prime}}{\ln \mathrm{s}}
$$

Keterangan:

E :indeks keseragaman

$\mathrm{H}^{\prime}$ :indeks keanekaragaman Shannon Wiener

$\mathrm{H}_{\max } \quad: \ln \mathrm{s}$

$\mathrm{S} \quad$ :jumlah spesies

\subsubsection{Indeks Dominansi $(C)$}

Dominansi dari suatu spesies dalam komunitas dapat diketahui dari hasil analisis dengan menggunakan Indeks Dominansi Simpson sebagai berikut (Krebs 2014):

$$
\mathrm{C}=\sum_{\mathrm{i}=1}^{\mathrm{s}}\left(\frac{\mathrm{ni}}{\mathrm{N}}\right)^{2}
$$

Keterangan:

C : Indeks Dominansi Simpson

ni : Jumlah individu masing-masing jenis

\subsubsection{A Marine Biotic Index (AMBI)}

Indeks AMBI digunakan untuk melihat nilai sensitivitas atau toleransi spesies. Nilai indeks ini dihitung dari jumlah kelimpahan relatif semua spesies di berbagai kelompok ekologis dengan rumus sebagai berikut (Borja et al. 2000).

$$
\mathrm{AMBI}=\frac{\left(\begin{array}{c}
(0 \times \% \mathrm{G} \mathrm{I})+(1,5 \times \% \mathrm{G} \mathrm{II})+(3 \times \% \mathrm{G} \mathrm{III}) \\
+(4,5 \times \% \mathrm{G} \mathrm{IV})+(6 \times \% \mathrm{G} \mathrm{V})
\end{array}\right)}{100}
$$

Keterangan:

G I :kelompok spesies sensitif

G II :kelompok spesies indefferent

G III :kelompok spesies toleran

G IV :kelompok spesies oportunistik urutan kedua

G V :kelompok spesies oportunistik orde 1

Klasifikasi nilai AMBI disajikan dalam Tabel 1 (Borja et al. 2000). 
Tabel 2. Hasil pengukuran beberapa parameter fisika-kimia perairan di Desa Pengujan.

\begin{tabular}{|c|c|c|c|c|c|c|c|}
\hline \multirow{2}{*}{ Parameter } & \multirow{2}{*}{ Satuan } & \multicolumn{5}{|c|}{ Nilai rata-rata } & \multirow{2}{*}{ Baku mutu } \\
\hline & & Stasiun 1 & Stasiun 2 & Stasiun 3 & Stasiun 4 & Stasiun 5 & \\
\hline \multicolumn{8}{|l|}{ Fisika } \\
\hline Suhu & ${ }^{\circ} \mathrm{C}$ & $28,2 \pm 0,3$ & $27,9 \pm 0,2$ & $27,4 \pm 1,2$ & $26,1 \pm 0,1$ & $28,0 \pm 0,3$ & $28-30$ \\
\hline Salinitas & $\%$ & $30,7 \pm 0,6$ & $31 \pm 0,0$ & $30,7 \pm 0,6$ & $31 \pm 0,6$ & $30 \pm 0,0$ & $33-34$ \\
\hline Kecerahan & $\mathrm{m}$ & $1,1 \pm 0,1$ & $0,8 \pm 0,1$ & $0,8 \pm 0,1$ & $0,9 \pm 0,1$ & $0,62 \pm 0,1$ & - \\
\hline TSS & $\mathrm{mg} / \mathrm{L}$ & $0,13 \pm 0,02$ & $0,13 \pm 0,02$ & $0,12 \pm 0,02$ & $0,13 \pm 0,02$ & $0,13 \pm 0,02$ & 80 \\
\hline TDS & $\mathrm{mg} / \mathrm{L}$ & $4710 \pm 127$ & $5010 \pm 419$ & $4570 \pm 69$ & $4860 \pm 364$ & $4800 \pm 0,0$ & - \\
\hline Substrat & - & $\begin{array}{c}\text { kerikil } \\
\text { berpasir }\end{array}$ & $\begin{array}{c}\text { pasir } \\
\text { berkerikil }\end{array}$ & $\begin{array}{c}\text { pasir } \\
\text { berkerikil }\end{array}$ & $\begin{array}{c}\text { pasir } \\
\text { berkerikil }\end{array}$ & $\begin{array}{c}\text { pasir } \\
\text { berkerikil }\end{array}$ & - \\
\hline \multicolumn{8}{|l|}{ Kimia } \\
\hline $\mathrm{pH}$ & - & $7,5 \pm 0,0$ & $7,8 \pm 0,0$ & $7,8 \pm 0,1$ & $8 \pm 0,1$ & $7,9 \pm 0,2$ & $7,0-8,5$ \\
\hline DO & $\mathrm{mg} / \mathrm{L}$ & $7 \pm 0,5$ & $7 \pm 0,3$ & $7 \pm 0,3$ & $7,1 \pm 0,5$ & $7,8 \pm 0,5$ & $>5$ \\
\hline $\mathrm{BOD}_{5}$ & $\mathrm{mg} / \mathrm{L}$ & $0,53 \pm 0,2$ & $0,5 \pm 0,5$ & $0,53 \pm 0,2$ & $0,53 \pm 0,2$ & $0,53 \pm 0,2$ & 20 \\
\hline TOM & $\%$ & $33,167 \pm 1,1$ & $33,116 \pm 0,7$ & $33,404 \pm 1,3$ & $31,668 \pm 1,6$ & $34,116 \pm 0,4$ & - \\
\hline Nitrat & $\mathrm{mg} / \mathrm{L}$ & $1,8 \pm 0$ & $1,4 \pm 0$ & $1,8 \pm 0$ & $2,2 \pm 0$ & $2,7 \pm 0$ & 0,06 \\
\hline Fosfat & $\mathrm{mg} / \mathrm{L}$ & $0,028 \pm 0$ & $0,266 \pm 0$ & $0,07 \pm 0$ & $1,978 \pm 0$ & $3,694 \pm 0$ & 0,015 \\
\hline
\end{tabular}

*Baku mutu berdasarkan PP RI No. 22 Tahun 2021 lampiran VIII

\section{Hasil dan Pembahasan}

\subsection{Hasil Kondisi Umum Perairan Desa} Pengujan Berdasarkan Parameter Fisika, Kimia dan Biologi Desa Pengujan

Hasil pengukuran parameter fisika-kimia perairan Desa Pengujan disajikan dalam Tabel 2. Suhu perairan di lokasi penelitian memiliki kisaran 26,1-28, $2^{\circ} \mathrm{C}$. Menurut Effendi (2003), cahaya matahari yang masuk ke perairan akan memengaruhi suhu perairan tersebut diakibatkan oleh proses penyerapan air, sehingga mengubahnya menjadi energi panas. Ditambahkan Ghufran (2007) bahwa semakin tinggi suhu semakin berkurang konsentrasi oksigen di dalam air yang disebabkan oleh adanya proses difusi antar air dengan udara bebas serta adanya proses fotosintesis. Meski demikian, nilai suhu tersebut dapat dikatakan layak untuk kehidupan makrozoobentos di perairan, hal ini sesuai dengan PP RI No. 22 Tahun 2021 tentang baku mutu air laut bahwa suhu yang baik untuk pertumbuhan biota berkisar $28-32^{\circ} \mathrm{C}$.

Salinitas di lokasi penelitian selama penelitian berkisar $30-31 \%$ oo. Salinitas merupakan suatu ukuran konsentrasi keseluruhan garam terlarut dalam air laut yang ikut memengaruhi kehidupan makrozoobentos
(Sianu et al. 2014). Menurut Lopo (2013), makrozoobentos jenis gastropoda umumnya mentoleransi salinitas yang berkisar antara 25$40 \%$. Secara umum kelompok filum Mollusca adalah organisme yang paling banyak ditemukan (Tabel3). Hal ini didukung dengan penelitian Rosdatina (2019) yang menyebutkan organisme ini mampu menahan perubahan salinitas dengan sangat baik, sehingga nilai salinitas yang diperoleh masih mendukung kehidupan makrozoobentos.

Kecerahan yang diperoleh berkisar antara 0,62-1,10 m. Kecerahan perairan merupakan indikator dari kejernihan suatu perairan yang berhubungan dengan penetrasi cahaya yang masuk ke kolom badan air. Semakin tinggi kecerahan maka semakin dalam penetrasi cahaya yang menembus perairan. Nilai kecerahan juga dipengaruhi oleh kondisi cuaca, Total Suspended Solid (TSS), dan waktu pengukuran. Mustofa (2018) menjelaskan bahwa kecerahan perairan dipengaruhi bahan-bahan tersuspensi baik berupa lumpur, bahan organik, plankton, serta mikroorganisme lainnya. Berdasarkan PP RI No. 22 Tahun 2021, nilai kecerahan tersebut masih dapat menunjang kehidupan makrozoobentos. 
Tabel 3. Hasil analisis jenis substrat di Perairan Pengujan.

\begin{tabular}{lccccc}
\hline \multirow{2}{*}{ Substrat } & \multicolumn{5}{c}{ Konsentrasi (\%) } \\
\cline { 2 - 6 } & Stasiun 1 & Stasiun 2 & Stasiun 3 & Stasiun 4 & Stasiun 5 \\
\hline Sand & 67,8 & 85,7 & 82,1 & 83,2 & 88,4 \\
Gravel & 32,2 & 14,3 & 17,9 & 16,8 & 11,6 \\
\hline Tekstur substrat & Kerikil & Pasir & Pasir & Pasir & Pasir \\
& berpasir & berkerikil & berkerikil & berkerikil & berkerikil \\
\hline
\end{tabular}

Total Suspended Solid (TSS) yang diperoleh di lokasi peneitian berkisar 0,12$0,13 \mathrm{mg} / \mathrm{L}$. TSS yaitu senyawa kimia yang terdapat dalam air baik dalam keadaan melayang, terapung maupun mengendap yang berukuran lebih besar dari $1 \mu \mathrm{m}$. Senyawa ini dijumpai dalam bentuk organik dan anorganik maupun deterjen yang tidak dapat langsung mengendap sehingga dapat menyebabkan kekeruhan air (Schaduw dan Ngangi 2015). Berdasarkan PP RI No. 22 Tahun 2021 nilai yang diperoleh masih tegolong baik dan masih dalam ambang batas. Menurut Mustofa (2018), total padatan tersuspensi mengandung bahan organik yang cukup tinggi yang dapat digunakan sebagai faktor penunjang kehidupan makrozoobentos.

Total Dissolved Solid (TDS) yang diperoleh berkisar antara 4570-5010 mg/L. Kadar TDS yang tinggi diakibatkan keberadaan senyawa-senyawa organik dan anorganik yang larut dalam air, berupa ion mineral dan garam. Air laut memiliki konsentrasi TDS yang tinggi karena banyak mengandung senyawa kimia yang mengakibatkan tingginya nilai salinitas (Afrianita et al. 2017). Nilai TDS perairan sangat dipengaruhi oleh pelapukan batuan, limpasan dari tanah dan pengaruh antropogenik (berupa limbah domestik dan industri).

Nilai pH di lokasi penelitian berkisar 7,58,0. Semakin tinggi nilai $\mathrm{pH}$, semakin tinggi nilai salinitas dan semakin rendah konsentrasi karbondioksida. Nilai $\mathrm{pH}$ yang diperoleh relatif lebih stabil dan cenderung basa, dengan kisaran nilai 7,5-8,0. Namun, dalam kondisi tertentu nilai ini dapat menjadi lebih rendah dan menjadi asam. Perubahan $\mathrm{pH}$ ini akan memengaruhi kualitas air yang selanjutnya memengaruhi umur biota. Adanya buangan limbah rumah tangga pada stasiun ini diduga dapat memengaruhi tingkat $\mathrm{pH}$. Menurut
Odum (1993), pada pH yang optimum organisme yang hidup di dalamnya akan bertahan, sebaliknya jika $\mathrm{pH}$ perairan terlalu tinggi atau terlalu rendah akan memengaruhi ketahanan hiduporganisme di dalamnya. Berdasarkan PP RI No. 22 Tahun 2021 nilai $\mathrm{pH}$ yang diperoleh masih tergolong baik dan masih dalam ambang batas.

Konsentrasi oksigen terlarut (DO) di lokasi penelitian berkisar 7,0-7,8 $\mathrm{mg} / \mathrm{L}$. Konsentrasi DO berbanding terbalik dengan TSS. Semakin tinggi konsentrasi TSS maka semakin rendah konsentrasi DO. Hal tersebut disebabkan karena terganggunya intesitas cahaya yang masuk ke dalam perairan sehingga proses fotosintesis oleh organisme autotrof menjadi tidak optimal. Konsentrasi oksigen terlarut meningkat sejalan dengan menurunnya suhu dan dengan meningkatnya salinitas. Hal ini juga sesuai dengan PP RI No. 22 Tahun 2021 bahwa konsentrasi oksigen terlarut untuk kehidupan biota perairan adalah $>5 \mathrm{mg} / \mathrm{L}$, maka dapat dikatakan bahwa konsentrasi oksigen terlarut di Perairan Desa Pengujan terbilang baik untuk biota makrozoobentos.

Konsentrasi Biochemical Oxygen Demand (BOD) di lokasi penelitian berkisar 0,50-0,53 mg/L. Menurut Saraswati et al. (2017), tingginya nilai $\mathrm{BOD}_{5}$ mengindikasikan tingginya konsentrasi bahan organik di suatu perairan. Putra et al. (2014) juga menyatakan bahwa $\mathrm{BOD}_{5}$ adalah salah satu indikator pencemaran organik pada suatu perairan. Perairan dengan konsentrasi $\mathrm{BOD}_{5}$ yang tinggi menunjukkan bahwa perairan tersebut tercemar oleh bahan organik. Berdasarkan PP RI No. 22 Tahun 2021 nilai yang diperoleh masih tergolong baik dan masih dalam ambang batas baku mutu perairan.

Total Organic Matter (TOM) di lokasi penelitian antara 33,116-34,116\%. Menurut Zulkifli et al. (2011), konsentrasi bahan 
Tabel 4. Jenis Makrozoobentos yang ditemukan di perairan Desa Pengujan.

\begin{tabular}{|c|c|c|c|c|c|c|c|}
\hline \multirow{2}{*}{ Filum } & \multirow{2}{*}{ Kelas } & \multirow{2}{*}{ Spesies } & \multicolumn{5}{|c|}{ Stasiun } \\
\hline & & & 1 & 2 & 3 & 4 & 5 \\
\hline \multirow[t]{12}{*}{ Mollusca } & \multirow[t]{9}{*}{ Gastropoda } & Cerithium coralium & $\sqrt{ }$ & $\sqrt{ }$ & $\mathrm{X}$ & $\mathrm{x}$ & $\mathrm{x}$ \\
\hline & & Nerita ocelllata & $\sqrt{ }$ & $\mathrm{x}$ & $\mathrm{x}$ & $\mathrm{x}$ & $\mathrm{x}$ \\
\hline & & Peristernia nassatula & $\sqrt{ }$ & $\mathrm{x}$ & $\mathrm{x}$ & $\mathrm{x}$ & $\sqrt{ }$ \\
\hline & & Luria cinerea & $\mathrm{x}$ & $\sqrt{ }$ & $\sqrt{ }$ & $\mathrm{x}$ & $\mathrm{x}$ \\
\hline & & Pirenella cingulata & $\mathrm{x}$ & $\mathrm{x}$ & $\sqrt{ }$ & $\mathrm{x}$ & $\mathrm{x}$ \\
\hline & & Rhinoclavis aspera & $\mathrm{x}$ & $\mathrm{X}$ & $\sqrt{ }$ & $\mathrm{x}$ & $\mathrm{x}$ \\
\hline & & Canarium urceus & $\mathrm{x}$ & $\mathrm{x}$ & $\mathrm{x}$ & $\sqrt{ }$ & $\mathrm{x}$ \\
\hline & & Laevistrombus canarium & $\mathrm{x}$ & $\mathrm{x}$ & $\mathrm{x}$ & $\mathrm{x}$ & $\sqrt{ }$ \\
\hline & & Littorina aspera & $\mathrm{x}$ & $\mathrm{x}$ & $\mathrm{x}$ & $\mathrm{x}$ & $\sqrt{ }$ \\
\hline & \multirow[t]{3}{*}{ Bivalvia } & Pitar floridana & $\mathrm{x}$ & $\sqrt{ }$ & $\mathrm{x}$ & $\mathrm{x}$ & $\mathrm{x}$ \\
\hline & & Anadara antiquata & $\mathrm{x}$ & $\mathrm{x}$ & $\sqrt{ }$ & $\mathrm{x}$ & $\mathrm{x}$ \\
\hline & & Meretrix lyrata & $\mathrm{x}$ & $\mathrm{x}$ & $\mathrm{x}$ & $\sqrt{ }$ & $\mathrm{x}$ \\
\hline \multirow[t]{4}{*}{ Arthopoda } & \multirow[t]{4}{*}{ Malacostraca } & Tubucapa radussumieri & $\sqrt{ }$ & $\mathrm{x}$ & $\mathrm{x}$ & $\mathrm{x}$ & $\mathrm{x}$ \\
\hline & & Macrophtalmus convexus & $\mathrm{x}$ & $\sqrt{ }$ & $\mathrm{x}$ & $\sqrt{ }$ & $\mathrm{x}$ \\
\hline & & Harpiosquilla raphidea & $\mathrm{x}$ & $\mathrm{x}$ & $\sqrt{ }$ & $\mathrm{x}$ & $\mathrm{x}$ \\
\hline & & Metapenaeus monoceros & $\mathrm{x}$ & $\mathrm{x}$ & $\mathrm{x}$ & $\sqrt{ }$ & $\mathrm{x}$ \\
\hline Echinodermata & Asteroidea & Luidia sarsi & $\mathrm{x}$ & $\mathrm{x}$ & $\sqrt{ }$ & $\sqrt{ }$ & $\mathrm{x}$ \\
\hline
\end{tabular}

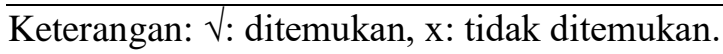

organik yang tinggi akan memengaruhi kelimpahan organisme. Beberapa organisme tertentu tahan terhadap tingginya konsentrasi bahan organik, sehingga dominansi oleh spesies tertentu dapat terjadi.

Konsentrasi nitrat di lokasi penelitian berkisar 1,4-2,7 mg/L, telah melebihi ambang batas baku mutu PP RI No. 22 Tahun 2021. Hutagalung dan Rozak (1997) mengatakan bahwa konsentrasi senyawa nitrat akan semakin meningkat dengan semakin rendahnya konsentrasi oksigen terlarut. Nasir et al. (2018) juga menyebutkan bahwa kegiatan rumah tangga dan budidaya biota perairan dapat memberikan banyak pasokan nutrien (N-P).

Konsentrasi fosfat di lokasi penelitian telah melebihi ambang batas baku mutu PP RI No. 22 Tahun 2021, berkisar 0,070-3,694 $\mathrm{mg} / \mathrm{L}$. Tingginya konsentrasi fosfat di stasiun 5 diduga karena adanya limbah yang dibuang langsung ke perairan serta meningkatnya pengadukan (turbulence) dasar perairan. Selanjutnya diduga akibat pengaruh musim utara (Desember, Januari, Februari) yang bertepatan dengan musim hujan. Hal ini dapat meningkatkan kadar fosfat yang berasal dari limpasan dari daratan. Menurut EPA (2002) dalam Patty et al. (2015), kadar fosfat >0,096 $\mathrm{mg} / \mathrm{L}$ tergolong tinggi; 0,048-0,096 $\mathrm{mg} / \mathrm{L}$ tergolong sedang; dan $<0,048 \mathrm{mg} / \mathrm{L}$ tergolong rendah. Berdasarkan hal ini, kadar fosfat pada Perairan Desa Pengujan tergolong tinggi sehingga diduga dapat memicu terjadinya eutrofikasi.

Tipe substrat di lokasi penelitian yaitu kerikil berpasir (stasiun 1) serta pasir berkerikil di stasiun 2-5 (Tabel 3). Substrat merupakan salah satu faktor yang sangat memengaruhi kehidupan, perkembangan dan keragaman makrozoobentos.

\subsection{Keanekaragaman Makrozoobentos}

Makrozoobentos yang ditemukan di Perairan Desa Pengujan, ditemukan 3 filum yang terdiri dari 4 kelas serta 13 genera. Ketiga filum tersebut antara lain Mollusca, Arthropoda, dan Echinodermata. Sementara 4 kelas yang ditemukan yaitu Gastropoda, Bivalvia, Malacostraca, dan Asteroidea. Jenis makrozoobentos yang ditemukan disajikan dalam Tabel 4. 


\subsection{Kepadatan Makrozoobentos}

Kepadatan makrozoobentos tertinggi berada di stasiun 3, sedangkan nilai kepadatan terendah berada di stasiun 5 (Gambar 2). Hal ini dapat dilihat dari jenis dan kepadatan organisme makrozoobentos yang bervariasi di setiap stasiun. Menurut Ulfah et al. (2012), kondisi lingkungan perairan, seperti parameter fisika kimia perairan memengaruhi kepadatan, komposisi, dan tingkat keragaman makrozoobentos.

Spesies yang paling banyak ditemukan pada stasiun 3 adalah Pirenella cingulate. Tingginya kepadatan makrozoobentos di stasiun 3 diduga karena konsentrasi bahan organik substrat yang cukup tinggi (Tabel 2). Sebagaimana yang dikatakan Ardi (2002) bahwa bahan organik merupakan salah satu sumber makanan bagi makrozoobentos jenis gastropoda. Choirudin et al. (2014) juga mengatakan bahwa makrozoobentos memiliki kaitan yang erat dengan ketersediaan bahan organik yang terkandung dalam substrat, karena bahan organik merupakan salah satu sumber nutrien bagi biota yang pada umumnya terdapat pada substrat dasar. Bahan organik akan berpengaruh penting baik secara langsung maupun tidak langsung terhadap kepadatan makrozoobentos. Kepadatan makrozoobentos yang rendah di stasiun 5 diduga disebabkan karena adanya aktivitas pengambilan makrozoobentos jenis siput gonggong dan bebrapa jenis kerang ekonomis penting. Kondisi tersebut secara tidak langsung menyebabkan tekanan ekologis terhadap biota sehingga dapat memengaruhi kepadatannya.

\subsection{Indeks Ekologi Makrozoobentos}

Nilai indeks keanekaragaman yang diperoleh dari kelima stasiun berkisar 0,801,60 (Tabel 5) Indeks keanekaragaman pada lokasi penelitian ini tergolong rendah. Tingkat keanekaragaman yang rendah menunjukkan bahwa penyebaran individu tiap jenis cenderung tidak merata serta kondisi kestabilan komunitas yang diduga cenderung rendah. Hal ini disebabkan semakin kecil jumlah spesies dan adanya individu yang jumlahnya lebih banyak mengakibatkan terjadinya ketidakseimbangan ekosistem yang kemungkinan disebabkan adanya tekanan ekologi atau gangguan dari lingkungan di sekitar (Desinawati et al. 2018).

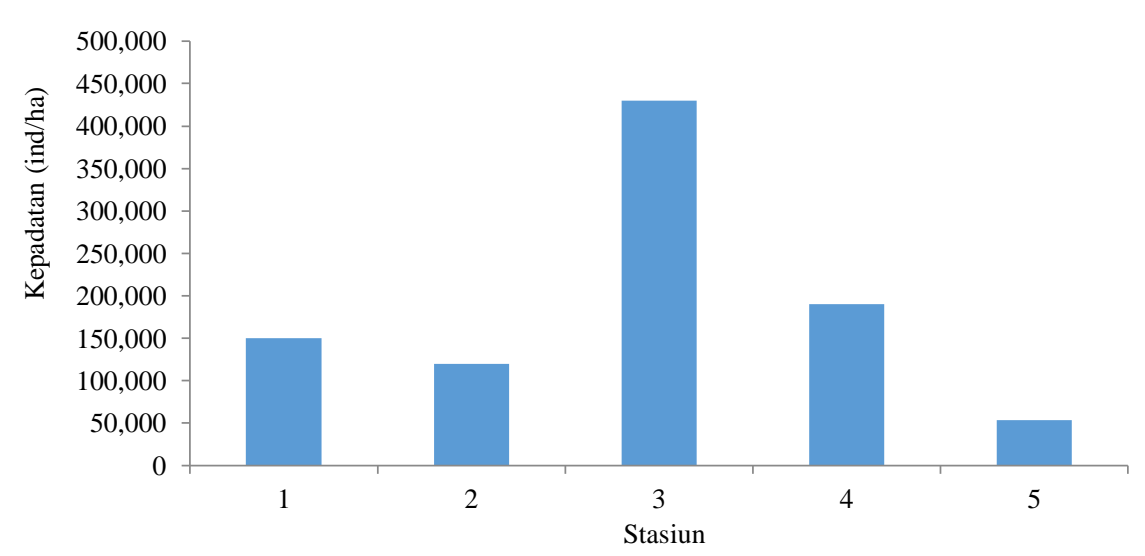

Gambar 2. Kepadatan makrozoobenthos di perairan Desa Pengujan.

Tabel 5. Indeks ekologi makrozoobentos di perairan Desa Pengujan.

\begin{tabular}{lccccc}
\hline \multirow{2}{*}{ Indeks } & \multicolumn{5}{c}{ Stasiun } \\
\cline { 2 - 6 } & 1 & 2 & 3 & 4 & 5 \\
\hline \multirow{2}{*}{ Keanekaragaman $\left(\mathrm{H}^{\prime}\right)$} & 1,37 & 0,80 & 1,60 & 1,31 & 0,98 \\
& Rendah & Rendah & Rendah & Rendah & Rendah \\
Keseragaman (E) & 0,99 & 0,57 & 0,82 & 0,73 & 0,90 \\
& Tinggi & Sedang & Tinggi & Tinggi & Tinggi \\
Dominansi (C) & 0,26 & 0,59 & 0,23 & 0,37 & 0,41 \\
& Rendah & Sedang & Rendah & Rendah & Rendah \\
\hline
\end{tabular}


Tabel 6. Daya toleransi makrozoobentos yang ditemukan di perairan Desa Pengujan

\begin{tabular}{cll} 
No. & Spesies & Sifat \\
\hline 1 & Cerithium coralium & Toleran (Indeks AMBI GIII) \\
2 & Nerita ocellata & Toleran (Indeks AMBI GIII) \\
3 & Peristernia nassatula & Toleran (Indeks AMBI GIII) \\
4 & Luria cinereal & Toleran (Indeks AMBI GIII) \\
5 & Pitar floridana & Toleran (Indeks AMBI GIII) \\
6 & Pinerella cingulata & Toleran (Indeks AMBI GIII) \\
7 & Rhinoclavis aspera & Toleran (Indeks AMBI GIII) \\
8 & Cacozeliana icarus & Toleran (Indeks AMBI GIII) \\
9 & Anadara antiquata & Toleran (Indeks AMBI GIII) \\
10 & Canarium urceus & Toleran (Indeks AMBI GIII) \\
11 & Meretrix lyrata & Toleran (Indeks AMBI GIII) \\
12 & Laevistrombus canarium & Toleran (Indeks AMBI GIII) \\
13 & Littorina aspera & Fakultatif (Indeks AMBI GII) \\
14 & Tubuca paradussumieri & Toleran (Indeks AMBI GIII) \\
15 & Macrophalmus convexus & Toleran (Indeks AMBI GIII) \\
16 & Harpiosquilla raphidea & Toleran (Indeks AMBI GIII) \\
17 & Metapenaeus monoceros & Toleran (Indeks AMBI GIII) \\
18 & Luidia sarsi & Fakultatif (Indeks AMBI GII) \\
\hline
\end{tabular}

Nilai indeks keseragaman yang diperoleh dari semua stasiun pengamatan berkisar $0,57-$ 0,99 . Indeks keseragaman pada lokasi penelitian ini tergolong tinggi. Menurut Odum (1993), keseragaman makrozoobentos yang tinggi menunjukkan bahwa jumlah individu setiap genus dapat dikatakan sama atau tidak jauh berbeda. Hal ini sesuai dengan pendapat Nurnaningsih (2000) yang menyatakan apabila genus yang diperoleh sedikit namun jumlah individu yang ditemukan dalam setiap genus relatif besar serta distribusi setiap genus tidak seimbang maka akan menyebabkan nilai keseragaman tinggi dan nilai keanekaragaman yang rendah.

Nilai indeks dominansi yang diperoleh dari kelima stasiun berkisar 0,23-0,59. Indeks dominansi pada lokasi penelitian ini tergolong rendah hingga sedang. Rosdatina et al. (2019) menyatakan nilai keseragaman berbanding terbalik dengan nilai dominansi. Apabila nilai keseragaman tinggi maka nilai indeks dominansinya rendah. Odum (1993) menyatakan nilai indeks dominansi yang tinggi menyatakan konsentrasi dominansi yang tinggi (ada individu yang mendominansi), sebaliknya nilai indeks dominansi yang rendah menyatakan konsentrasi yang rendah (tidak ada yang dominan).

\subsection{Kualitas Perairan Desa Pengujan Berdasarkan Keberadaan Makrozoobentos}

Masing-masing spesies makrozoobentos yang ditemukan di perairan Desa Pengujan dapat dijadikan indikator terhadap kondisi lingkungan berdasarkan daya toleransinya terhadap pencemar (Tabel 6). Kondisi lingkungan berdasarkan nilai AMBI disajikan dalam Gambar 3.

Kondisi kualitas perairan berdasarkan makrozoobentos di perairan Desa Pengujan termasuk dalam kategori sedikit tercemar (Gambar 3). Nilai AMBI terendah terdapat di stasiun 5 yaitu sebesar 2,50 disebabkan karena ditemukannya jenis fakultatif seperti gastropoda dan bivalvia yang memiliki peran penting bagi kestabilan ekosistem, terutama rantai makanan dan membantu dalam mendekomposisi organisme yang telah mati. Kondisi seperti ini tidak lepas dari sifat hidup makrozoobentos yang memiliki mobilitas rendah dan cenderung stabil, sehingga dapat menerima perubahan kondisi lingkungan yang terjadi. Makrozoobentos jenis fakultatif seperti 


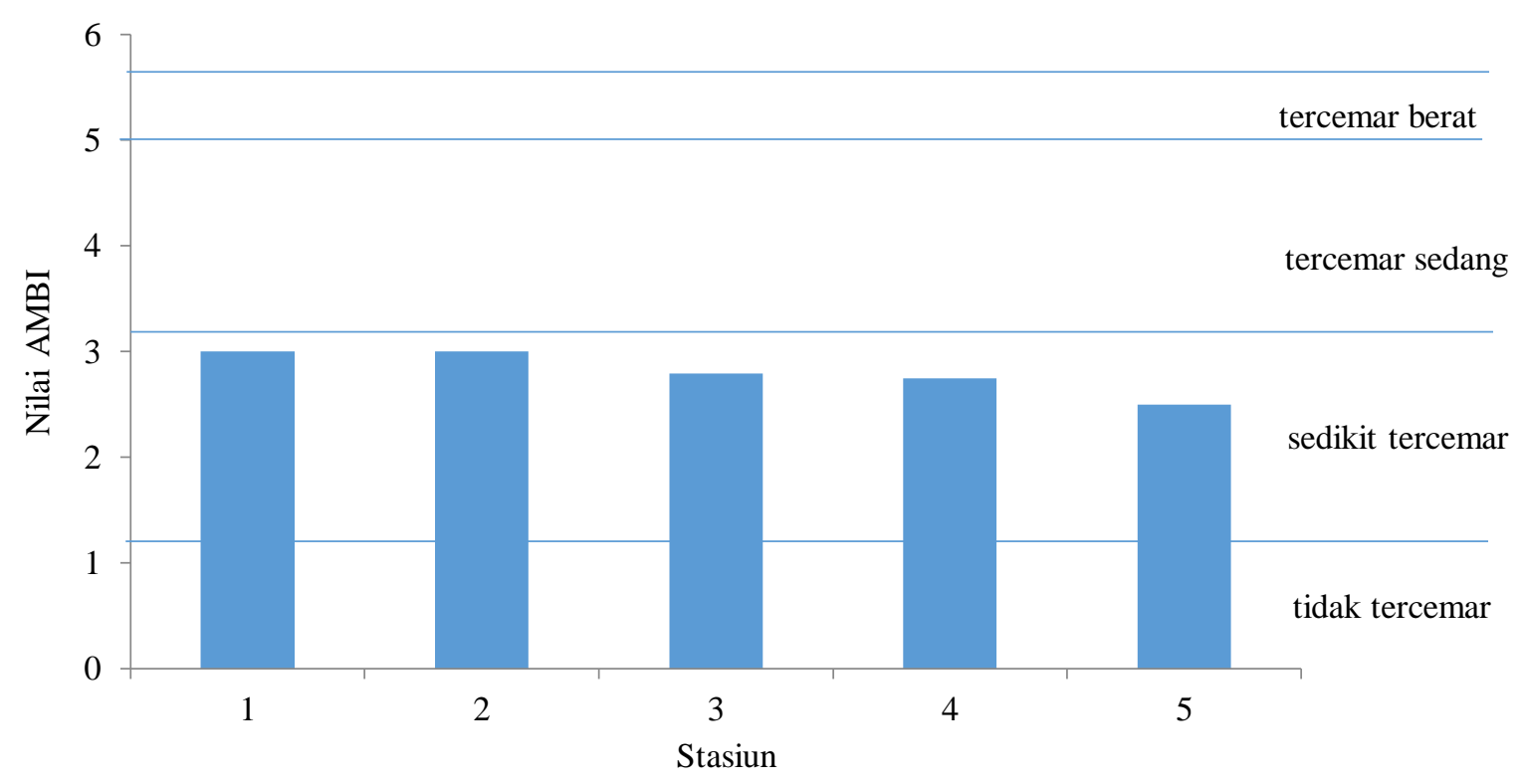

Gambar 3. Kondisi perairan Desa Pengujan berdasarkan nilai AMBI.

gastropoda memiliki individu yang lebih banyak dibandingkan dengan makrozoobentos jenis lainnya dan memiliki tingkat migrasi yang lebih rendah, yang menunjukkan bahwa perairan tersebut terkontaminasi oleh beberapa bahan organik. Hal tersebut disebabkan pengaruh arus air yang membawa limbah dari aktivitas masyarakat ke perairan tersebut. Menurut Dwitawati et al. (2015), makrozoobentos dari kelas gastropoda memiliki toleransi yang baik dengan kondisi perairan yang tercemar ringan sampai tercemar berat

\section{Kesimpulan}

Parameter fisika dan kimia perairan Desa Pengujan masih berada pada ambang batas baku mutu PP RI No. 22 Tahun 2021 tentang Penyelenggaraan Perlindungan dan Pengelolaan Lingkungan Hidup Lampiran VIII peruntukkan Baku Mutu Air Laut serta masih mendukung untuk kehidupan makrozoobentos kecuali untuk parameter nitrat dan fosfat yang tidak memenuhi baku mutu di setiap stasiunnya. Nilai kepadatan makrozoobentos tertinggi yaitu pada stasiun 3 dengan total kepadatan berjumlah 430.000 ind/ha, sedangkan makrozoobentos dengan nilai kepadatan terendah yaitu pada stasiun 5 dengan total kepadatan $53.333 \mathrm{ind} / \mathrm{ha}$. Kategori indeks keanekaragaman (H') pada semua stasiun dikategorikan "rendah". Kategori indeks keseragaman (E) pada stasiun 1 "tinggi", 2 "sedang", serta 3, 4 dan 5 dikategorikan "tinggi". Kategori indeks dominansi (C) pada stasiun 1 "rendah", stasun 2 "sedang", stasiun 3,4 dan 5 "rendah". Kualitas perairan di Desa Pengujan AMBI termasuk dalam kategori "sedikit tercemar".

\section{Daftar Pustaka}

Afrianita R, Edwin T, Alawiyah A. 2017. Analisis intrusi air laut dengan pengukuran Total Dissolved Solids (TDS) air sumur gali di Kecamatan Padang Utara. Jurnal Teknik Lingkungan. 14(1):62-72.

[APHA] American Public Health Association. 2017. Standart Methods for The Examination of Water and Wastewater $23^{\text {rd }}$ ed. Maryland(US): United Book Press Inc.

Apriadi T, Muzammil W, Melani WR, Safitri A. 2020. Struktur komunitas makrozoobenthos di aliran sungai di Senggarang, Pulau Bintan, Kepulauan Riau. Depik Jurnal Ilmu-Ilmu Perairan, Pesisir dan Perikanan. 9(1):119-130.

Ardi. 2002. Pemanfaatan makrozoobentos sebagai indikator kualitas perairan pesisir. [tesis] Bogor(ID): Institut Pertanian Bogor.

Arhat P, Widada S, Saputro S. 2014. Studi sebaran sedimen dasar dan kondisi arus di Perairan Keling, Kabupaten Jepara. Jurnal Oseanografi. 3(4):683-689.

Armanda D. 2018. Tingkat pemanfaatan siput gonggong (Strombus sp.) di perairan Desa 
Pengujan Kabupaten Bintan. [skripsi] Tanjungpinang(ID): Universitas Maritim Raja Ali Haji.

Borja A, Franco J, Perez V. 2000. A marine biotic index to establish the ecological quality of soft-bottom benthos within European Estuarine and coastal environments. Marine Pollution Bulletin. 40(12):1114-2000.

Choirudin IR, Supardjo MN, Muskananfola MR. 2014. Studi hubungan konsentrasi bahan organik sedimen dengan kelimpahan makrozoobentos di muara Sungai Wedung Kabupaten Demak. Diponegoro Jurnal of Maquares. 3(3):168-176.

Desinawati, Adi W, Utami E. 2018. Struktur komunitas makrozoobentos di Sungai Pakil Kabupaten Bangka. Akuatik Jurnal Sumberdaya Perairan. 1(3):54-63.

Dwitawati D, Ani S, Joko W. 2015. Biomonitoring kualitas air Sungai Gandong dengan bioindikator makroinvertebrata sebagai bahan petunjuk praktikum pada pokok bahasan pencemaran lingkungan SMP Kelas VII. Jurnal Florea. 2(1):41-46.

Effendi H. 2003. Telaah Kualitas Air Bagi Pengelolaan Sumber Daya dan Lingkungan. Yogyakarta(ID): Kanisius. 98 hlm.

Efriningsih R, Puspita L. Ramses. 2016. Evaluasi kualitas lingkungan perairan pesisir di sekitar TPA Telaga Punggur Kota Batam berdasarkan struktur komunitas makrozoobenthos. Jurnal Simbiosa. $5(1): 1-15$.

[FAO] Food and Agriculture Organization. 1998. Living Marine Resources of The Western Central Pacific Volume 1: Seaweeds, corals, bivalves and gastropods. Editor: Carpenter KE, Niem VH. Roma: Food and Agriculture Organization of The United Nation.

Ghufran HM, Kordi K, Andi BT. 2007. Pengelolaan Kualitas Air dalam Budidaya Perairan. Jakarta(ID): Rineka Cipta.

Hutagalung HP, Rozak A. 1997. Metode Analisis Air Laut, Sedimen dan Biota.
Jakarta(ID): Pusat Penelitian dan Pengembangan Oseanologi-LIPI. 175 hlm.

Junaidi. 2017. Analisis hubungan kerapatan lamun dengan kelimpahan makrozoobentos di Perairan Selat Bintan Desa Pengujan Kabupaten Bintan Provinsi Kepulauan Riau. [skripsi] Pekanbaru(ID): Universitas Riau.

Krebs CJ. 2014. Ecological Methodology. Third Edition. Online access. http://www.zoology.ubc.ca/ krebs/books.h tml.

Lopo Y. 2013. Diversitas jenis gastropoda sebagai bioindikator kualitas perairan pantai Kecamatan Kota Lama Kota Kupang. [skripsi] Kupang(ID): Universitas PGRI.

Mustofa A. 2018. pengaruh total padatan tersuspensi terhadap biodiversitas makrozoobentos di Pantai Telukawur Kabupaten Jepara. Jurnal Disprotek. 9(1):37-45.

Nasir A, Baiduri MA, Hasniar. 2018. Nutrien N-P di perairan pesisir Pangkep, Sulawesi Selatan. Jurnal Ilmu dan Teknologi Kelautan Tropis. 10(1):135-141.

Nurnaningsih. 2000. Struktur komunitas makrozoobentos di perairan Sungai Banjaran dan Sungai Kranji Kabupaten Banyumas, Jawa Tengah. [skripsi] Bogor(ID): Institut Pertanian Bogor.

Odum EP. 1993. Dasar-dasar Ekologi. Diterjemahkan oleh Tjahjono Samingan. Yogyakarta(ID): Universitas Gajah Mada Press.

Patty SI, Arfah H, Abdul MS. 2015. Zat hara (fosfat, nitrat), oksigen terlarut, dan $\mathrm{pH}$ kaitannya dengan kesuburan di Perairan Jikumerasa, Pulau Buru. Jurnal Pesisir dan Laut Tropis. 1(1):43-50.

Pengujan Simdes Bintan. 2021. Sistem informasi manajemen desa di Kabupaten Bintan. [internet] Diakses pada 29 Januari 2021. Tersedia pada: https://www.pengujan.simdes-bintan.id/.

[PP RI] Peraturan Presiden Republik Indonesia. 2021. Peraturan Presiden Republik Indonesia Nomor 22 Tahun 2021 
Lampiran VIII Tentang Penyelenggaraan Perlindungan dan Pengelolaan Lingkungan Lingkungan Hidup Peruntukkan Baku Mutu Air Laut.

Prihatin N, Melani WR, Muzammil W. 2021. Struktur komunitas makrozoobentos dan kaitannya dengan kualitas Perairan Kampung Baru, Desa Sebong Lagoi, Kabupaten Bintan. Jurnal Pengelolaan Perikanan Tropis. 5(1):20-28.

Putra DS. 2015. Keanekaragaman gastropoda di perairan litoral Pulau Pengujan Kabupaten Bintan. [skripsi] Tanjungpinang(ID): Universitas Maritim Raja Ali Haji.

Putra H, Izmiarti, Afrizal. 2014. Komunitas makrozoobentos di Sungai Batang Ombilin Sumatera Barat. Jurnal Biologi. 3(3):175182.

Rosdatina Y, Apriadi T, Melani WR. 2019. Makrozoobentos sebagai bioindikator kualitas Perairan Pulau Penyengat, Kepulauan Riau. Jurnal Pengelolaan Lingkungan Berkelanjutan. 3(2):309-317.

Safitri A, Melani WR, Muzammil W. 2021. Komunitas makrozoobentos dan kaitannya dengan kualitas air aliran sungai Senggarang, Kota Tanjungpinang. Acta Aquatica. 8(2):103-108.

Saraswati NLGRA, Arthana IW, Hendrawan IG. 2017. Analisis kualitas perairan pada wilayah Perairan Pulau Serangan bagian utara berdasarkan baku mutu air Laut. Journal of Marine and Aquatic Sciences. 3(2):163-170.
Schaduw JN, Ngangi E. 2015. Karakterisasi lingkungan Perairan Teluk Talengen Kabupaten Kepulauan Sangihe sebagai kawasan budidaya rumput laut Kappaphycus Alvarezii. Journal Budidaya Perairan. 3(2):29-44.

Sianu NE, Sahami FM, Kasim F. 2014. Keanekaragaman dan asosiasi gastropoda dengan ekosistem lamun di Perairan Teluk Tomini. Nikè Jurnal Ilmiah Perikanan dan Kelautan. 2(4):156-163.

Ulfah Y, Widianingsih, Zainuri M. 2012. Struktur komunitas makrozoobentos di perairan wilayah Morosari Desa Bedono Kecamatan Sayung Demak. Journal of Marine Research. 1(2):188-196.

Zulkifli H, Hanafiah Z, Puspitawati DA. 2011. Struktur dan Fungsi Komunitas Makrozoobenthos di Perairan Sungai Musi Kota Palembang: Telaah Indikator Pencemaran Air. Prosiding Seminar Nasional Biologi. Meningkatkan Peran Biologi dalam Mewujudkan National Achievement with Global Reach. Sabtu, 22 Januari 2011. Medan: USUPress. Halaman 586-595. 